\title{
OPTIMIZATION OF INVERTASE ASSAY CONDITIONS IN RUBBER TREE PLANTS (Hevea brasiliensis Muell. Arg.) ${ }^{1}$
}

\author{
Daria Pimenta de Oliveira², Luiz Edson Mota de Oliveira ${ }^{3}$ e Nelson Delú Filho ${ }^{4}$
}

\begin{abstract}
The objective of this work was to define the optimal conditions for invertase assay, seeking to determine the ideal parameters for the different isoenzymes of leaf and bark tissues in adult rubber trees. Assays of varying $\mathrm{pH}$, sucrose concentration and temperature of the reaction medium were conducted for the two investigated isoenzymes. The results pointed out the existence of two different $\mathrm{pH}$ related isoforms for the two analyzed tissues, with an isoenzyme being more active at pH 5,5 and the other at neutral/alkaline $\mathrm{pH}$. Leaf blade isoenzymes presented similar values for substrate concentration, whereas the bark isoenzyme presented maximum values below those previously reported. The assays at different temperatures presented similar values for leaf isoenzymes, though they have differed significantly among the obtained values.
\end{abstract}

Keywords: invertase assay, isoenzyme, rubber trees.

\section{OTIMIZAÇÃO DAS CONDIÇÕESS DO ENSAIO DA INVERTASE EM SERINGUEIRA (Hevea brasiliensis Muell. Arg.) ${ }^{I}$}

\begin{abstract}
RESUMO - O objetivo deste trabalho foi definir as condições ótimas para a realização do ensaio enzimático da invertase, procurando-se determinar os parâmetros ideais para as diferentes isoenzimas de tecidos foliares e da casca de plantas adultas de seringueira. Foram realizados ensaios variando-se o $\mathrm{pH}$, a concentração da sacarose e a temperatura do meio de reação para as duas isoenzimas estudadas. Os resultados indicaram a existência de duas isoformas diferentes em relação ao pH nos dois tecidos analisados, sendo uma isoenzima mais ativa a pH 5,5 e outra em pH neutro/alcalino. Com relação à concentração do substrato, as isoenzimas da lâmina foliar apresentaram valores semelhantes, enquanto a isoenzima da casca, valores máximos inferiores aos observados anteriormente. Os ensaios conduzidos em diferentes temperaturas tiveram valores semelhantes nas isoenzimas da folha, embora tenham diferido significativamente entre dos valores obtidos.
\end{abstract}

Palavras chave: ensaio da invertase, isoenzimas, seringueira.

\section{INTRODUCTION}

Invertase acts upon the catalysis of sucrose irreversible hydrolysis producing both fructose and glucose. Invertases can be classified according to their subcellular localization, their ideal $\mathrm{pH}$ of activity and respective isoelectric points (AVIGAD, 1982). Acid invertases are located inside the vacuole and the cell wall (KRISHNAN et al., 1984; SALZER and HAGER, 1993), whilst neutral or alkaline invertases occur in the cytosol of plant cells (STURN and CHRISPEELS, 1990). Another classification takes into account the solubility of the different isoenzymes present in the cell. Soluble invertases are, therefore, always intracellular and differ in their optimum $\mathrm{pH}$; acid invertases have ideal $\mathrm{pH}$ between 3.5 and 5.1, and neutral or alkaline

\footnotetext{
${ }^{1}$ Recebido em 17.07.2002 e aceito para publicação em 05.04.2006.

${ }^{2}$ Forest Enginneer, MSc. Fisiologia Vegetal/UFLA

${ }^{3}$ Professor - Departamento de Biologia/Fisiologia Vegetal/UFLA (ledson@ufla.br)

${ }^{4}$ Professor - Universidade Vale do Rio Verde, Três Corações-MG, (ndelu @ unincor.br)
} 
invertases have optimum $\mathrm{pH}$ between 7 and 7.8. The invertase ionically bound to the cell wall in the apoplast has ideal pH around 4.5 (AVIGAD, 1982).

When the sucrose coming from the source tissues arrives at the sites of utilization, it is first hydrolyzed to fructose and glucose before being utilized in a metabolic process. There are two possible sites in the plant cell for the occurrence of this event. In some cases, sucrose is hydrolyzed in the apoplastic region of sink tissue cells, in a reaction catalyzed by the acid invertase, covalently bound to the cell wall. The result of this reaction is the production of glucose and fructose molecules that are assimilated by the cells with the participation of hexoses carriers located in the plasmatic membrane (TUBBE and BUCKHOUT, 1992; YLSTRA et al., 1998). Another alternative would be the wholly sucrose entry into the plant cell, mediated by the sucrosebinding protein (GRIMES et al., 1992), allowing, from this point on, to be hydrolyzed by cytosol neutral invertase or sucrose synthase.

Plant invertases have been widely studied and many have been purified from a great variety of plant species, remaining, however, doubts about the precise function of the different isoenzymes. It has been proposed that soluble invertases take part in the regulation of hexose levels in mature leaves (RICARDO, 1974; RICARDO and SOVIA, 1974) and fruits (LINGLE and DUNLOP, 1987), and in the mobilization of sucrose stored in the vacuoles, being responsible for the regulation of cell turgescence (LEIGH et al., 1979). Extracellular carrot invertase was the first to be cloned in higher plants (STURN and CHRISPEELS, 1990), and, more recently, others clones of intra and extracellular invertases have been isolated and sequenced (ARAI et al., 1992; KLANN et al., 1992; HEDLEY et al.; 1993; WU et al., 1993). Some researchers have suggested an important role of extracellular invertases in carbohydrate partitioning. Transgenic plants overexpressing yeast invertase in the apoplast (STITT et al., 1990; von SCHAEWEN et al., 1990; DICKINSON et al., 1991) demonstrated the source regulation by sink tissues. There was accumulation of carbohydrates in plants presenting antisense constructs, causing photosynthesis inhibition, and increase in the respiratory rate and greater carbohydrate accumulation in sink organs of sense plants.

Deficiencies in the invertase activity in mutant corn plants miniature- 1 caused aberrant pedicel and endosperm development (MILLER and CHOUREY, 1992).
Evidences obtained from those mutants indicate that the invertase activity directly affects metabolism and, consequently, the development of the seed mother cells.

However, it is not clear yet the precise role of invertases in some types of sink-tissues, such as the rubber bark, latex synthesis site, whose biosynthesis starts precisely with the arrival of sucrose at those tissues. The objective of this work was to define optimal assay conditions of invertase, in leaf and bark tissues, to provide a better understanding of the variation in latex production of rubber plants.

\section{MATERIALS AND METHODS}

Bleeding: Latex extraction was carried out in adult rubber trees of two different clones (RRIM 600 and GT-1) by the half spiral technique, in the D3/D4 system.

Plant Material: leaf blades at developmental stages $\mathrm{B}$ and $\mathrm{D}$ and bark samples were removed from adult plants of clone RRIM 600. The collected material was immediately frozen in liquid $\mathrm{N}_{2}$ and stored at $-86^{\circ} \mathrm{C}$ until use. Each repetition consisted of four trees.

Latex: after being clotted, latex was transferred into a paper bag and maintained in an oven at $70^{\circ} \mathrm{C}$ to constant weight. The latex used for the enzyme analyses was collected and immediately transported in ice to the laboratory, $1 \%$ Triton X-100 (v/v) was then added to the samples followed by centrifugation at $12.000 \mathrm{~g}$ for 30 minutes at $4^{\circ} \mathrm{C}$, the fraction Serum $\mathrm{C}$ was collected and stored in ice until enzyme analyses.

Extraction: $1 \mathrm{~g}$ of plant material was homogenized in a microgrinder for 20 seconds, for 3 times, in $10 \mathrm{~mL}$ of $50 \mathrm{mmol} / \mathrm{L}$ phosphate buffer, $1 \mathrm{mmol} / \mathrm{L} \mathrm{2-}$ mercaptoethanol, $5 \mathrm{mmol} / \mathrm{L}$ manganese sulfate, $\mathrm{pH}$ 7.5. After homogenization, the extract was filtered in six layers of gauze, centrifuged at $18,000 \mathrm{~g}$ for 20 minutes at $4^{\circ} \mathrm{C}$, and stored at this temperature until utilization (crude extract).

Partial Purification of Invertases: the obtained crude extract was saturated with ammonium sulfate to $60 \%(\mathrm{w} / \mathrm{v})$, stored for 12 hours at $4^{\circ} \mathrm{C}$, following centrifugation at $18.000 \mathrm{~g}$ for 20 minutes at $4^{\circ} \mathrm{C}$. The precipitate was resuspended at the rate of $2 \mathrm{~mL}$ of the extracting solution per gram of tissue, and the sample was desalinized in Sephadex G-25 column.

Optimization of the assay conditions: the invertase assay was performed according to Vattuone et al. (1981). 
The reaction medium consisted of $1 \mathrm{~mL}$ x $0.2 \mathrm{~mol} / \mathrm{L}$ sucrose, $2.7 \mathrm{~mL}$ x $50 \mathrm{mmol} / \mathrm{L}$ phosphate buffer at the desired $\mathrm{pH}$, and $0.3 \mathrm{~mL}$ enzyme extract. The reaction started with the addition of the enzyme extract, at constant temperature of $37^{\circ} \mathrm{C}$ for 30 minutes. After the 30 minutes, invertase activity was determined by reducing sugar dosage (MILLER, 1959). Invertase activity was evaluated through the parameters $\mathrm{pH}$ (3.5 to 9 , with 0.5 unit intervals), temperature ( 17 to 57 , with $10^{\circ} \mathrm{C}$ intervals) and sucrose concentration $(0,10,20,50,100$ and 200 $\mathrm{mmol} / \mathrm{L})$ of the reaction medium.

\section{RESULTS AND DISCUSSION}

Figure 1 shows the results of dry rubber production in different months of the year, for two different clones of rubber tree. Variation in dry rubber production is found for both the collecting seasons and for a same clone, as well as between clones in a same season. The variability, both in the environmental conditions and genotype, is the subject of investigation of this work. Invertase is related with phloem discharge into sink organs, a possible explanation for the found variations is related with the different activity of isoenzymes over the year and also among different genetic materials. This enzyme is likely to be a biochemical marker for screening potentially more productive plant materials, allowing, further, via HMM technique (early bleeding carried out in plants of approximately 2 years), the screening of genetic materials of high productive

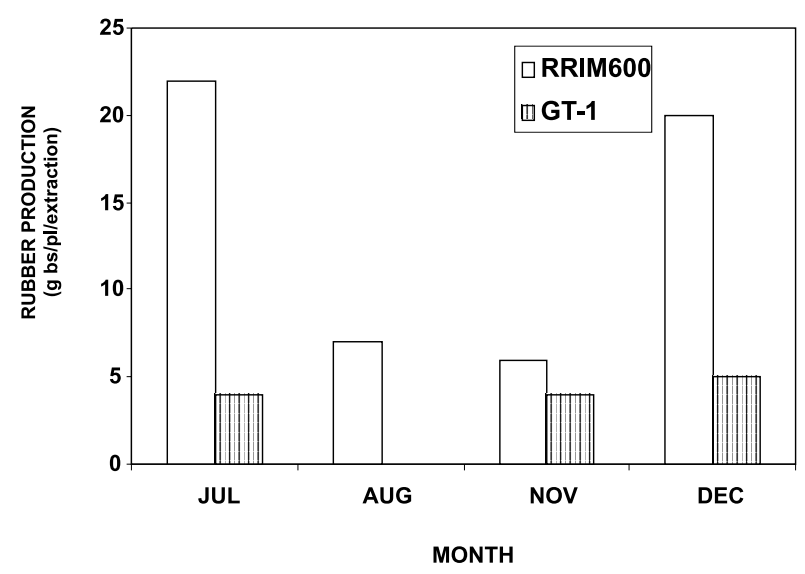

Figure 1 - Variation in dry rubber yield at different times of the year in 2 rubber tree clones. Mean of 4 replicates.

Figura 1 - Variação na produção de borracha seca em diferentes épocas do ano e em dois diferentes clones de seringueira. Média de quatro repetições. potential, since the conventional rubber tree breeding takes approximately 30 years to establish a new clone, whereas the biochemical method, in case correlation exists, will reduce the time to no more than 2 years.

The effect of the variation in the $\mathrm{pH}$ of the reaction medium on the activity of soluble invertase isoenzymes in different plant tissues was evaluated (Figure 2). Two activity peaks were found for protein extracts obtained from growing leaves, one at $\mathrm{pH} 5$ and another at $\mathrm{pH}$ 7. The highest activity value was, in general, obtained for the assay at $\mathrm{pH} 5$, indicating that the soluble isoenzyme present in the vacuole is the main responsible for sucrose hydrolysis during this stage of leaf development. On the other hand, in already developed leaves, maximum activity values for enzyme activity were obtained between pHs 6.5 and 7.5, which characterize hydrolysis mediated by neutral cytosol isoenzyme. It has been proposed that soluble invertases take part in the regulation of hexose levels in mature leaves (RICARDO, 1974; RICARDO and SOVIA, 1974) and fruits (LINGLE and DUNLOP, 1987) and also in the remobilization of sucrose stored in the vacuole (LEIGH et al., 1979). Sturn (1999) proposed that alkaline invertase is the main responsible for sucrose hydrolysis in rapidly developing tissues, which contradicts the results obtained in this work. It was also found that the activity in bark showed no peaks; values for invertase activity above $\mathrm{pH} 4$ were not significantly different.

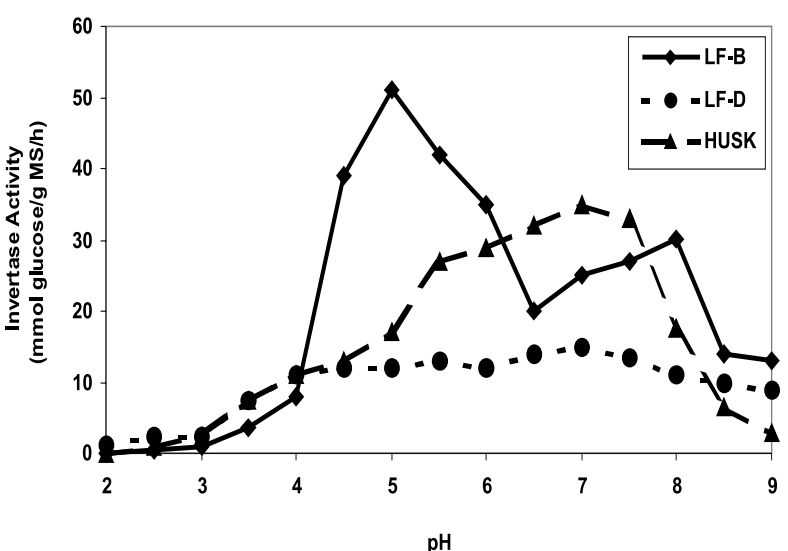

Figure 2 - Activity of invertase in fully expanded (LF-D), growing (LF-B) leaf blade and bark of rubber tree plants, as a function of the reaction medium $\mathrm{pH}$. Means of 4 replicated.

Figura 2-Atividade da invertase em lâmina foliar completamente expandida ( $L F-D)$, em crescimento $(L F-B)$ e em casca de plantas de seringueira, em função do $\mathrm{pH}$ do meio de reação. Média de quatro repetições.

R. Árvore, Viçosa-MG, v.30, n.5, p.687-692, 2006 
Invertase activity increased linearly with the sucrose concentration in the reaction medium (Figure 4), reaching maximum at 50 and $100 \mathrm{mmol} / \mathrm{L}$ of sucrose for isoenzymes of expanding and fully expanded leaves, respectively. It is worth pointing out that the assays were performed on the basis of previous results for $\mathrm{pH}$ (Figure 2). The maximum activity for bark isoenzymes (Figure 5) was obtained in the assay with $100 \mathrm{mmol} /$ $\mathrm{L}$ of sucrose. The results allowed $\mathrm{Km}$ and $\mathrm{Vmax}$ calculations (Table 1), which give the precise concentration to develop the work within the linear range of the catalytic curve, according to the definition of Michaelis-Menten kinetic parameters. In addition, Table 1 shows that the 3 studied isoenzymes presented different values for $\mathrm{Km}$ and Vmax parameters.

It is known that the velocity of a particular reaction is a function of temperature, being a determinant factor mainly in biological systems, in which extreme temperatures can affect negatively the enzymatic catalysis, for causing denaturation or increasing medium viscosity, and consequently making enzyme turnover difficult. In view of this, this work sought to evaluate invertase activity at different temperatures of the reaction medium (Figure 3), as well as to define an optimum temperature for the assay, aiming at the evaluation of rubber plants at different times of the year, considering the significant differences in temperature over the

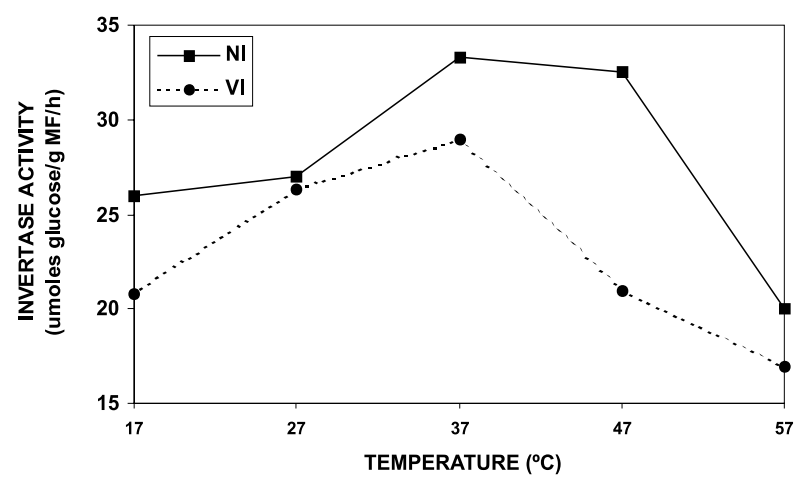

Figure 3 - Activity of invertase in fully expanded leaf blade in rubber trees, as a function of the reaction medium temperature. Means of 4 replicates. (NI and VI identify neutral invertase and vacuolar invertase, respectively).

Figura 3 -Atividade da invertase em lâmina foliar completamente expandida em plantas de seringueira, em função da temperatura do meio de reação. Média de quatro repetições (NI e VI identificam invertase neutra e invertase do vacúolo, respectivamente). different seasons. The highest invertase activity was obtained for the two isoenzymes when the assay was conducted at $37^{\circ} \mathrm{C}$, in spite of neutral invertase having presented activity significantly higher than acid invertase of the vacuole.

The results obtained in this work led to the conclusion that the highest activity of acid invertase were found in young leaves, whereas neutral invertase has optimum temperature of activity higher than vacuolar invertase. In addition, the invertase activity in young leaves had lower $\mathrm{km}$ for sucrose than in fully expanded leaves.

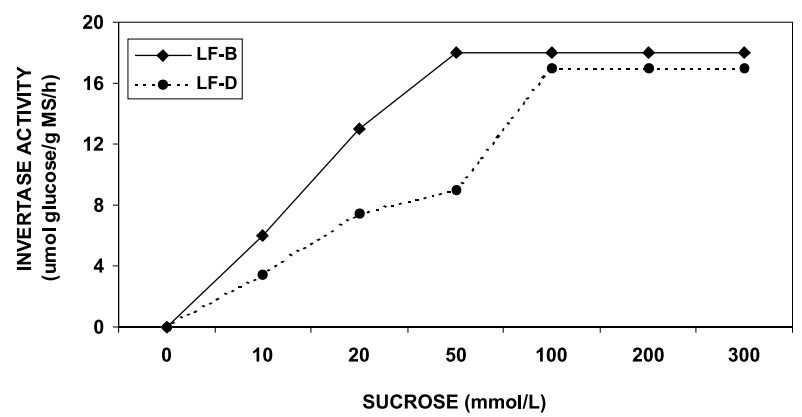

Figure 4-Activity of invertase in fully expanded and growing (LF-D) and (LF-B) leaf blade in rubber trees, as a function of the sucrose concentration in the reaction medium. Mean of 4 replicates.

Figura 4-Atividade da invertase em lâmina foliar completamente expandida $(L F-D)$, em crescimento $(L F-B)$ e em plantas de seringueira, em função da concentração de sacarose no meio de reação. Média de quatro repetições.

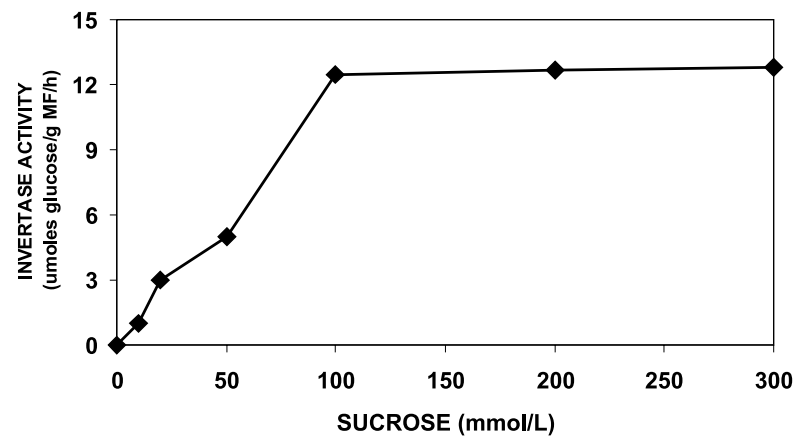

Figure 5 - Invertase activity in the bark of rubber tree plants, as a function of the sucrose concentration in the reaction medium. Mean of 4 replicates.

Figura 5 - Atividade da invertase na casca de plantas de seringueira, em função da concentração de sucrose no meio de reação. Média de quatro repetições. 
Table 1 - Kinetic parameters for the enzyme invertase in different types of plant tissues

Tabela 1 - Parâmetros cinéticos para a enzima invertase em diferentes tipos de tecido vegetal

\begin{tabular}{|c|c|c|c|}
\hline & Expanded Leaf & Growing Leaf & Bark \\
\hline $\mathrm{K}_{\text {maxapp }}(\mathrm{mM})$ & 40,80 & 13,89 & 111,34 \\
\hline $\mathrm{V}_{\text {maxapp }}\left(\right.$ umoles.s $\left.{ }^{-1}\right)$ & $\left.{ }^{1}\right) \quad 21,33$ & 20,63 & 23,15 \\
\hline
\end{tabular}

\section{REFERENCES}

ARAI, M.; MORI, H.; IMASEKI, H. Cloning and sequence of cDNAs for an intracellular invertase from etiolated hypocotyls of mung bean and expression on the gene during growth of seedlings. Plant and Cell Physiology, v. 33, n. 3, p. 245-252, 1992.

AVIGAD, G. Sucrose and other disaccharides. In: F.A. LOEWUS, W.T. (Eds.), Encyclopedia of Plant Physiology (New Series). Berlin: Spring-Verlag, 1982. p. 216-347.

DICKINSON, C.D.; ALTABELLA, T.; CHRISPEELS, M.J. Slow-growth phenotype of transgenic tomato expressing apoplastic invertase. Plant

Physiology, v. 95, n. 2, p. 420-425, 1991.

GRIMES, H.D.; OVERVOORDE, P.J.; HIPP, K. A62-kD sucrose binding protein is expressed and localized in tissues actively engaged in sucrose transport. The Plant Cell, v. 4, n. 12, p. 1561-1574, 1992.

HEDLEY, P.E. et al. cDNA cloning and expression of a potato (Solanum tuberosum) invertase. Plant Molecular Biology, v. 22, n. 4, p. 917-922, 1993.

KLANN, K.E.; YELLE, S.; BENNETT, A.B. Tomato fruit acid invertase complementary DNA. Plant Physiology, v. 99, n. 2, p. 351-353, 1992.

KRISHNAN, H.B.; BLANCHETTE, J.T.; OKITA, T.W. Wheat invertases: characterization of cell wall-bound and soluble forms. Plant

Physiology, v. 78, p.241-245, 1984.

LEIGH, R.A. et al. The location of invertase activity and sucrose in the vacuoles of storage roots of beet root (Beta vulgaris). Biochemical Journal, v. 178 , p. $539-547,1979$.

LINGLE, S.E.; DUNLOP, J.R. Sucrose metabolism in netted musk-melon fruit during development. Plant Physiology, v. 84, p. 386-389, 1987.
MILLER, E.M.; CHOUREY, P.S. The maize invertasedeficient miniature- 1 seed mutation is associated with aberrant pedicel and endosperm development. The Plant Cell, v. 4, n. 3, p. 297-305, 1992.

RICARDO, C.P.P. Alkaline b-fructosidase of tuberous roots: possible physiological function. Planta, v. 118, n. 2, p. 333-343, 1974.

RICARDO, C.P.P.; SOVIA, D. Development of tuberous roots and sugar accumulation as related to invertase activity and mineral nutrition.

Planta, v. 118, n. 1, p. 43-55, 1974.

SALZER, P.; HAGER, A. Characterization of wallbound invertase isoforms of Pices abies and regulation by ectomycorrhizal fungi. Physiology Plantarium, v. 88, n. 1, p. 52-59, 1993.

STITT, M.; von SCHAEWEN, A.; WILLMITZER, L. "Sink" regulation of photosynthetic metabolism in transgenic tobacco plants expressing yeast invertase in their cell wall involves a decrease of the Calvin-cycle enzymes and an of glycolytic enzymes. Planta, v. 183, n. 1, p. 40-50, 1990.

STURN, A. Invertases. Primary structures, functions, and roles in plant development and sucrose partitioning. Plant Physiology, v. 121, p. $1-7,1999$.

STURN, A.; CHRISPEELS, M.J. cDNA cloning of carrot extracellular b-fructosidase and expression in response to wounding and bacterial infection. The Plant Cell, v. 2, p. 1110-1119, 1990.

TUBBE, A.; BUCKHOUT, T.J. In vitro analysis of the $\mathrm{H}^{+}$-hexose symporter on plasma membrane of sugarbeets (Beta vulgaris L.). Plant

Physiology, v. 99, n. 3, p. 945-951, 1992.

VIEIRA, A.A. et al. Biochemical evaluation of lipoxygenase pathway of soybean plants submitted to wounding. Revista Brasileira de Fisiologia Vegetal, v. 13, n. 1, p. 05-12, 2001.

von SCHAEWEN, A. et al. Expression of a yeastderived invertase in the cell wall of tobacco and Arabidopsis leaves to accumulation of carbohydrate and inhibition of photosynthesis and strongly influences growth and phenotype of transgenic tobacco plants. The EMBO Journal, v. 9, n. 11, p. 3033-3034, 1990. 
YLSTRA, B. et al. Hexose transporter in growing petunia pollen tuber and characterization of a pollen-specific putative monosaccharide transporter. Plant

Physiology, v. 118, p. 297-304, 1998.
WU, L.L. et al. Kinetic induction of oat shoot pulvinus invertase mRNA by gravistimulation and partial cDNA cloning by polymerase chain reaction. Plant Molecular

Biology, v. 21, n. 5, p. 1175-1179, 1993. 